\title{
Correlation of copper/zinc ratio with superoxide dismutase activity and neutrophil-to-lymphocyte ratio in human immunodeficiency virus type 1 (HIV-1) infected subjects
}

\author{
Mathias A. Emokpae \\ Department of Medical Laboratory Science, University of Benin, Benin City, Nigeria
}

\begin{abstract}
Introduction: The important role of nutrition in the pathogenesis of human immunodeficiency virus type-1 (HIV-1) infection has not been sufficiently addressed in sub-Sahara Africa, where the prevalence of HIV infection is high. This study correlates copper-to-zinc ratio with activities of superoxide dismutase and calculated neutrophil-to-lymphocyte ratio in HIV-1-infected subjects.

Material and methods: In the study, there were 120 confirmed HIV-1 positive subjects and $100 \mathrm{HIV}-1$ negative ambulatory healthy controls. Complete blood count, clusters of differentiation (CD4+) lymphocyte count, serum superoxide dismutase (SOD), catalase, copper, and zinc were evaluated using hematology analyzer, FACS flow cytometer, enzyme-linked immunosorbent assay, and atomic absorption spectrophotometer, respectively. Correlation between the measured variables was completed using Pearson correlation coefficient.

Results: Serum copper $(p<0.001)$, catalase $(p<0.05)$, and neutrophil-to-lymphocyte ratio (NLR) $(p<0.001)$ were significantly higher, while serum zinc $(p<0.001)$ was lower in HIV-1 positive than control subjects. Copper/zinc ratio correlated with SOD $(r=-0.228 ; p<0.02), \mathrm{CD}^{+}(-0.235 ; p<0.02)$, and $\operatorname{NLR}(r=0.198 ; p<0.05)$ in HIV infected subjects.

Conclusions: Copper/zinc ratio correlated with NLR, SOD, and $\mathrm{CD} 4^{+}$cell count. Because of the adverse effects associated with imbalance of copper and zinc levels, nutritional status, antioxidant defense mechanism, and inflammatory markers may be assessed periodically in HIV-1-infected patients.
\end{abstract}

HIV AIDS Rev 2018; 17, 1: 18-23 DOI: https://doi.org/10.5114/hivar.2017.72278

Key words: human immunodeficiency virus, copper, zinc, copper-to-zinc ratio, superoxide dismutase.

\section{Introduction}

Human immunodeficiency virus type 1 (HIV-1) is a major health challenge all over the world $[1,2]$, especially in sub-Sahara Africa. The understanding of the biology of HIV

Address for correspondence: Dr. Mathias A. Emokpae, Department of Medical Laboratory Science, University of Benin, 300001 Benin, Nigeria, phone: +2348034511182 ,

e-mail: mathias.emokpae@uniben.edu infection had advanced, and the introduction of anti-retroviral therapy has greatly improved the prognosis and reduced mortality of the infected individuals [3]. The vital role of host nutrition in the pathogenesis of HIV infection has not been adequately addressed especially in sub-Sahara
Article history:

Received: 23.05.2017

Received in revised form: 07.10.2017

Accepted: 08.10.2017

Available online: 15.11.2017
International Journal of HIV-Related Problems

HIV \& AIDS

$R$ e vi e w 
Africa, where a large population of infected individuals live below poverty level, hence nutritional deficiency is a major challenge that needs to be adequately addressed. The immune function of the human body is largely dependent on nutritional status. Apart from immune-deficiency, which is the hallmark of HIV infection, opportunistic infections [4-6] inflammation and oxidative stress [7] are additional disease burden that underscores the need for adequate nutrition in HIV infection. There are numerous studies that had evaluated serum levels of copper and zinc in individuals with HIV-1 infection [8-12], but evidence of the relationship between copper/zinc ratio with markers of inflammation, disease progression, and antioxidant enzymes are scare in our setting.

The use of copper/zinc ratio as an important inflammatory and nutritional marker has been advocated and in fact used to predict all-cause mortality in several disease conditions. An increase in the serum copper/zinc is a non-specific reaction to inflammation. It was suggested that the serum copper/zinc ratio is clinically of utmost importance because it constitutes a tool to establish disease severity in chronic illnesses $[13,14]$. Serum copper and zinc are regulated by metallothioneins such that when copper level decreases, zinc level will increases, and vice versa. Their levels in the body are lower in several disease conditions [15] and are not disease specific, but follow a pattern of metabolism [16]. The interpretation of individual trace element level may be problematic because their levels in serum may not reflect their cellular status due to homeostasis control mechanism. Therefore, the ratio may be preferred to better indicate their levels in clinical practice [17].

Neutrophil-to-lymphocyte ratio (NLR) is used as a marker of sub-clinical inflammation [18], and for general immune response to various stimuli including HIV infection, sickle cell anemia [19], and cancers [20-22]. Neutrophil-to-lymphocyte ratio was reported to be associated with severity of clinical progress in severely ill patients [23]. In this study, we used NLR as marker of inflammation in HIV-1-infected subjects.

Superoxide dismutase (SOD) and catalase are enzymes that belong to the anti-oxidant defense systems, helping to scavenge free radicals generated in the body that could cause damage to biomolecules. The antioxidant defense system is extensive and made up of several steps that protect against free radicals at different sites [24]. This study seeks to evaluate the activities of SOD and catalase, levels of clusters of differentiation $\left(\mathrm{CD}^{+}\right)$, serum copper, zinc, and calculated NLR in HIV-1-infected subjects and correlates their levels/ activities with copper/zinc ratio.

\section{Material and methods}

This is cross-sectional, case-control, and laboratorybased study of confirmed HIV-1-infected and healthy control subjects. The study participants who were consecutively recruited included 120 confirmed HIV-1 positive individuals (40 males with mean age of $32.9 \pm 0.4$ years, and $60 \mathrm{fe}-$ males with mean age of $30.5 \pm 0.4$ years), and 100 HIV-1 negative (apparently healthy) individuals recruited among staff and students of our institution (controls, 40 males with mean age of $32.6 \pm 0.3$ years, and 60 females with mean age of $31.9 \pm 0.2$ years).

\section{Inclusion and exclusion criteria}

All HIV-1 positive subjects registered at the HIV clinic of Central Hospital, Benin City, Nigeria and willing to participate in the study were included. All hemolyzed samples, patients with lymphoma, rheumatoid arthritis, ulcerated colitis, celiac, Menkes syndrome, and Wilson's disease were excluded.

\section{Ethical consideration}

The research protocol was reviewed and approved by the Ethics and Research Committee of the Edo State Ministry of Health (ethical code HM.1208/112, dated $12^{\text {th }}$ May, 2016).

Informed consent was obtained from all participants and utmost confidentiality of information was maintained.

\section{Specimen collection and analytical methods}

Six milliliters of blood sample was collected by venous puncture; $3 \mathrm{ml}$ was dispensed into a plain tube, while the remaining $3 \mathrm{ml}$ was emptied into bottle containing ethylene diamine tetra-acetic acid (EDTA). The sample in the plain container was allowed to clot at room temperature. The clotted sample was centrifuged at $3000 \mathrm{rpm}$ for $10 \mathrm{~min}$, and the serum was separated and kept frozen at $-20^{\circ} \mathrm{C}$ until analyzed. The serum SOD and catalase (CAT) were assayed by enzyme linked immunosorbent assay (ELISA) technique using reagent kits supplied by Wkea Med Supplies Corp., Changchun, China. The experiments were completed according to the manufacturer's protocol.

The complete blood count and $\mathrm{CD} 4^{+}$count were assayed using the Coulter counter hematology analyzer (CELL DYE 3700, Abbott Diagnostics, Wiesbaden, Germany) and fluorescence activated cell sorter (FACS flow cytometer) count system, Lincolnshire, IL, USA, respectively. The NLR was calculated by dividing the value of absolute neutrophil count by absolute lymphocyte count obtained from complete blood count. Serum copper and zinc levels were measured using atomic absorption spectrophotometer (Atomic Absorption spectrophotometer AA-680, Shimadzu, Japan). Both test and standard concentrations were read in duplicate, and their mean values were used for statistical comparison.

\section{Statistical analysis}

The data obtained from this study were analyzed using SPSS version 21 (SPSS Inc., Chicago, IL, USA) for Windows. The mean levels of measured variables and enzymes activi- 
Table 1. Levels of copper, zinc, copper/zinc ratio and anti-oxidant enzymes in HIV-1-positive subjects compared with controls

\begin{tabular}{l|c|c|c}
\hline Measured parameters & $\begin{array}{c}\text { HIV-1-positive subjects } \\
(n=120)\end{array}$ & $\begin{array}{c}\text { HIV-1-negative control } \\
\text { subjects }(n=100)\end{array}$ & $p$-value \\
\hline Serum catalase $(\mu \mathrm{g} / \mathrm{l})$ & $14.9 \pm 0.85$ & $11.5 \pm 0.05$ & 0.05 \\
\hline Serum SOD $(\mathrm{ng} / \mathrm{ml})$ & $1.61 \pm 0.01$ & $1.81 \pm 0.02$ & 0.001 \\
\hline Serum copper $(\mu \mathrm{g} / \mathrm{dl})$ & $165.6 \pm 2.1$ & $141.1 \pm 2.4$ & 0.001 \\
\hline Serum zinc $(\mu \mathrm{g} / \mathrm{dl})$ & $77.5 \pm 1.9$ & $96.5 \pm 1.5$ & 0.001 \\
\hline Copper/zinc ratio & $2.12 \pm 0.02$ & $1.45 \pm 0.03$ & 0.001 \\
\hline SOD- superoxide dismutase &
\end{tabular}

Table 2. Comparison of complete blood count, $\mathrm{CD}^{+}$cell count, and neutrophil-to-lymphocyte level between HIV-1-positive and HIV-1-negative subjects

\begin{tabular}{l|c|c|c}
\hline Measured parameters & HIV-1-positive subjects & HIV-1-negative subjects & $p$-Value \\
\hline PCV $(\%)$ & $35.5 \pm 0.32$ & $38.8 \pm 0.50$ & 0.001 \\
\hline $\mathrm{Hb}(\mathrm{g} / \mathrm{dl})$ & $11.8 \pm 0.10$ & $13.7 \pm 0.09$ & 0.001 \\
\hline Total WBC $\left(\times 10^{9} / \mathrm{l}\right)$ & $5.8 \pm 0.11$ & $4.9 \pm 0.15$ & 0.001 \\
\hline Platelet count $\left(\times 10^{9} / \mathrm{l}\right)$ & $262.0 \pm 7.5$ & $307 \pm 8.5$ & 0.01 \\
\hline Neutrophil $\left(\times 10^{9} / \mathrm{l}\right)$ & $3.75 \pm 0.09$ & $2.51 \pm 0.08$ & 0.001 \\
\hline Lymphocyte $\left(\times 10^{9} / \mathrm{l}\right)$ & $1.93 \pm 0.05$ & $2.14 \pm 0.07$ & 0.005 \\
\hline NLR & $1.93 \pm 0.01$ & $1.16 \pm 0.02$ & 0.001 \\
\hline
\end{tabular}

PCV - packed cell volume, $\mathrm{Hb}$ - hemoglobin, WBC - white blood cell, NLR - neutrophil-to-lymphocyte ratio

ties were compared between cases and controls, while copper/zinc ratio was correlated with NLR, SOD, catalase, and $\mathrm{CD} 4{ }^{+}$cell count of HIV-1-infected subjects using Pearson's correlation coefficient. A $p$-value $<0.05$ was considered statistically significant.

\section{Results}

Table 1 shows the levels of copper, zinc, copper/zinc ratio and antioxidant enzymes compared between HIV-1-infected subjects and controls. Serum copper $(p<0.001)$, catalase $(p<0.05)$, and calculated copper/zinc ratio $(p<0.001)$ were significantly higher, while SOD and zinc level were significantly lower $(p<0.001)$ in HIV-1-infected adults than control subjects.

The packed cell volume $(p<0.001)$, hemoglobin $(p<0.001)$, platelet count $(p<0.01)$, and absolute lymphocyte count $(p<0.05)$ were significantly lower, while total white blood cell count, absolute neutrophil count, and calculated NLR were significantly higher $(p<0.001)$ in cases than controls (Table 2).

Table 2 shows that copper/zinc ratio correlate negatively with SOD $(r=-0.228 ; 0.02)$ and CD4 $(r=-0.235$; $p<0.02)$, while NLR $(0.198 ; p<0.05)$ correlated positively in HIV-1 positive subjects. However, the correlation between copper/zinc ratio and catalase activity was not statistically significant.

\section{Discussion}

Serum copper and zinc play important roles in immunophysiologic functions of the human body $[6,25,26]$. Zinc is a co-factor for several enzymes and play critical roles in nucleic acid metabolism, cell replication, tissue repair, and growth. Copper on the other hand, is present in cytosolic erythrocyte superoxide dismutase (Cu, $\mathrm{Zn}$ SOD), which is an important antioxidant against superoxide radical. Deficiency in their levels may lead to changes in thymic function with resultant depletion of immunity, inflammation, and increased susceptibility to infectious diseases [25-27].

We observed significantly lower level of zinc, higher level of copper as well as elevated levels of calculated copper/ zinc ratio and NLR in HIV-1-infected subjects than controls. The elevated level of copper/zinc ratio correlated with $\mathrm{CD} 4^{+}$ count, SOD, and NLR.

The observed higher level of copper coupled with lower level of zinc in HIV-1-infected subjects is consistent with previous studies [8, 28-32]. Whereas Neil et al. [32] reported a significantly higher mean copper levels than controls, Khalili et al. [33] observed significantly lower zinc levels in HIV-infected subjects than controls. A significantly higher level of copper, regardless of gender, was also reported by Moreno et al. [34]. The authors suggested that copper may be used as a surrogate marker of inflammatory diseases. This observation was faulted by some authors who supposed 
Table 3. Correlation of copper-to-zinc ratio with antioxidant enzymes and neutrophil-to-lymphocyte ratio in HIV-1-positive subjects

\begin{tabular}{l|c|c}
\hline Correlated variables & $R$-value & $p$-value \\
\hline Cu/Zn ratio/neutrophil-to-lymphocyte ratio & 0.198 & 0.05 \\
\hline Cu/Zn ratio/catalase & 0.167 & 0.10 \\
\hline Cu/Zn ratio/superoxide dismutase & -0.228 & 0.02 \\
\hline Cu/Zn ratio/CD4+ cell count & -0.235 & 0.02 \\
\hline
\end{tabular}

that copper levels are not good markers of inflammatory response because its concentration appears to reflect interactions among different pathological processes [35]. Copper participates in low-density lipoprotein-cholesterol (LDL-c) oxidation within artery walls, deficiency, and overconsumption of copper can lead to atherogenesis [36, 37]. HIV-1 infection could adversely impact nutritional status either by reduced food intake, impair absorption, and/or increasing utilization of nutrients [8]. Arinola et al. [28] attributed their finding of elevated copper level to the use of unregimented measure in the treatment of diseases in their environment. They suggested that most HIV-infected individuals seek all forms of unorthodox treatment such as herbs and dietary advice [8]. Low levels of zinc have long been reported to lower lymphocyte concentration [38-40]. The imbalance in zinc and copper concentrations (high copper/zinc ratio) in HIV infection are caused by impair utilization of zinc due to perturbation in protein synthesis, decreased intestinal absorption, and muscle wasting associated with HIV infection. Pinolic acid, a derivative of tryptophan metabolism acts as zinc binding ligand, and facilitates its absorption and distribution in the body [11].

Micronutrients deficiency is common in sub-Sahara Africa, and may be a contributing factor to weakening immune status and thus, exacerbating clinical manifestation of HIV-1 infection [41]. Micronutrients (particularly copper and zinc) are important modulators of immunity and could modify the risk of infection $[42,43]$. The higher levels of copper observed in HIV-1-infected subjects may indicate a non-specific increase of copper-binding protein caeruloplasmin $[44,45]$. Plasma concentrations of caeruloplasmin and copper may increase as an acute-phase response in several infectious diseases and inflammatory conditions [46]. The higher copper/zinc value, as observed in this study, is consistent with that of Malviya et al. [3]. They observed a significantly negative correlation between copper/zinc ratio with CD4 cell count. The copper/zinc ratio increased with decreasing concentration of CD4 cell count, while zinc level decreased with decreasing concentration of CD4 cell count. Some authors have utilized copper/zinc ratio for the clinical evaluation of zinc deficiency in several diseases [47]. In a study of HIV-positive homosexual men, it was concluded that copper/zinc ratio $>1.0$ may be associated with increased mortality [48]
It was therefore suggested that the ratio may be used to predict patient survival and disease progression in HIV patients [48]. Results from our study tend to support possible use of copper/zinc ratio as a useful marker of HIV activity and disease progression.

Copper/zinc ratio correlated positively with NLR ratio, which may indicate the presence of subclinical inflammation in HIV-1 infection. A higher NLR was used as a predictor of cardiovascular (CVD) risk in HIV-infected individuals, independently of other traditional CVD risk factors [49], predictor of mortality for non-AIDS defining cancer, and for non-Hodgkin lymphoma in HIV-infected subjects $[50,51]$. HIV infection is a disease associated with chronic inflammation and increased levels of inflammation; immune activation and endothelial dysfunction biomarkers have been reported [52, 53]. Neutrophil-to-lymphocyte ratio is an emerging marker of systemic inflammation, which had been observed to predict mortality in many disease conditions $[54,55]$.

Copper/zinc ratio correlated negatively $(r=0.228$; $p<0.02)$ with SOD, while a non-significant correlation was observed with catalase. This indicates that copper/zinc ratio increased with decreasing activity of SOD in this study. Zinc and copper act as co-factors for SOD, an important antioxidant enzyme. Imbalance of these trace elements in the body may affect the enzyme activity. This observation was verified by other authors [56]. Such imbalance can contribute to oxidative stress, an imbalance in the generation of free radical and availability of antioxidant protection mechanism, and a situation that can compromise immune system and worsened by HIV-1 infection [57, 58].

\section{Conclusions}

This study observed higher calculated copper/zinc ratio, NLR, serum copper, and lower serum zinc levels in HIV-1-infected subjects than controls. Copper/zinc ratio correlated with NLR, SOD, and CD4 ${ }^{+}$cell count. HIV-1 infection and associated adverse effects of higher copper/zinc ratio underscore the need to evaluate and monitor the nutritional status, antioxidant defense mechanism, and inflammatory markers periodically in this patients. If the imbalance is corrected, it may help to stop disease progression, improve immunity, and reduce inflammation.

\section{Acknowledgements}

We would like to thank the study participants, clinical and laboratory staff of Central Hospital, Benin City for their contributions towards completion of this study.

\section{Conflict of interest}

The author's declared no potential conflicts of interest with respect to the research, authorship, and/or publication of this article. 


\section{References}

1. Allard JP, Aghdassi E, Chau J, et al. Oxidative stress and plasma antioxidant micronutrients in humans. Am J Clin Nutr 1998; 67: 143-147.

2. Abrams B, Duncan D, Hertz-Picciotto I. A prospective study of dietary intake and acquired immune deficiency syndrome in HIV seropositive homosexual men. J Acquir Immune Defic Syndr 1993; 6: 949-958.

3. Malviya A, Hassan H, Hussain A. Correlation of CD4+T cell count with serum zinc, copper, and selenium in HIV positive individuals. Internet J Epidemiol 2008; 6: 1-6.

4. Kassu A, Yabutani T, Mahmud ZH, et al. Alterations in serum levels of trace elements in tuberculosis HIV infection. Eur J Clin Nutr 2006; 60: 580-586.

5. Roy SK, Raqib R, Khatun W, et al. Zinc supplementation in the management of shigellosis in malnourished children in Bangladesh. Eur J Clin Nutr 2004; 62: 849-855.

6. Amare B, Tafess K, Moges F, et al. Levels of Serum Zinc, Copper and Copper/Zinc Ratio in Patients with Diarrhea and HIV Infection in Ethiopia. Vitam Trace Elem 2011; 1: 101.

7. Emokpae MA, Mrakpor BA. Do Sex Differences in Respiratory Burst Enzyme Activities Exist in Human Immunodeficiency Virus-1 Infection? Med Scis 2016; 4: 1-8.

8. Akinjinmi AA, Akingbade OA, Okerentugba PO, et al. Evaluation of selenium and zinc levels in seropositive HIV individuals in a tertiary Hospital in Osogbo, Osun State Nigeria. Academ Arena 2013; 5: 17-21.

9. Elatif MA, Hassan EE, Bakhit SM, et al. Assessment of plasma zinc and copper levels among Sudanese HIV patients in Khartoum state. Int J Adv Pharm Biol Chem 2014; 3: 395-399.

10. Drain PK, Kupka R, Mugusi F, et al. Micronutrients in HIV positive persons receiving highly active antiretroviral therapy. Am J Clin Nutr 2007; 85: 333-345.

11. Ibeh IN, Nwokenna US. Studies on cations as biomarkers of mammalian immunity: prospects in disease control. J Natl Acad Adv Sci 2003; 2: 89-109.

12. Kupka R, Msamanga GI, Spiegelman D, et al. Selenium status is associated with accelerated HIV disease progression among HIV-1-infected pregnant women in Tanzania. J Nutr 2004; 134: 2556-2560.

13. Mao S, Huang S. Zinc and copper levels in bladder cancer: a systemic review and meta-analysis. Biol Trace Elem Res 2013; 153: 5-10.

14. Poo JL, Romero RR, Robles JA, et al. Diagnostic value of copper/zinc ratio in digestive cancer: a case control study. Arch Med Res 1997; 28: 259-263.

15. Ibeh IN, Nwokenna US, Onemu S, et al. Studies on disease markers in a Nigerian community. Natl J Sci 2002; 1: 20-25.

16. Malapati BR, Nadeem DR, Patel B, et al. Serum zinc and copper levels in HIV positive patients. Eur J Parmaceut Med Res 2015; 2: 265-270.

17. Osredkar J, Sustar N. Copper and zinc, biological role and significance of copper/zinc imbalance. J Clin Toxicol 2011; 5: 3.

18. Minardi D, Scartozzi M, Montesi L, et al. Neutrophil-to-lymphocyte ratio may be associated with the outcome in patients with prostate cancer. Springer Plus 2015; 4: 255.

19. Emokpae MA, Aruomaren A, Osime E. Relationship between Neutrophil-to-Lymphocyte Ratio and Inflammatory Markers in Sickle Cell Anaemia Patients with Proteinuria. Med Sci 2016; 4: 1-8.

20. Pinato DJ, Stavraka C, Flynn MJ, et al. An inflammation-based score can optimize the selection of patients with advanced cancer considered for early phase clinical trial. PLos One 2014; 1-10: e83279.

21. Li MX, Liu XM, Zhang XF, et al. Prognostic role of neutrophil-tolymphocyte ratio in colorectal cancer: a systematic review. Int J Cancer 2014; 134: 2403-2413.

22. Grivennikov SI, Greten FR, Karin M. Immunity, inflammation and cancer. Cell 2010; 140: 833-899.
23. Zahorec R. Ratio of neutrophil to lymphocyte count - rapid and simple parameter of systemic inflammation and stress in critically ill. Bratisl Lek Listy 2001; 102: 5-14.

24. Uadia PO, Emokpae MA. Implications of Oxidative Stress on Male Infertility. Transaction of the Nigerian Society of Biochemistry and Molecular Biology 2015; 1: 19-29.

25. Failla ML. Trace elements and host defense: recent advances and continuing challenges. J Nutr 2003; 133: 1443S-1447S.

26. Stern BR, Solioz M, Krewski D, et al. Copper and Human Health: biochemistry, genetics, and strategies for modeling dose-response relationships. J Toxicol Environ Health B Crit Rev 2007; 10: 157-222.

27. Tomkins A. Assessing micronutrient status in the presence of inflammation. J Nutr 2003; 133: 1649S-1655S.

28. Arinola OG, Adedapo KS, Kehinde AO, et al. Acute phase proteins, trace elements in asymptomatic human immunodeficiency virus infection in Nigerians. Afr J Med Med Sci 2004; 33: 317-322.

29. Semba RD, Caiaffa WT, Graham NM, et al. Vitamin A deficiency and wasting as predictors of mortality in human immunodeficiency virusinfected injection drug users. J Infect Dis 1995; 171: 1196-1202.

30. Coodley GO, Coodley MK, Nelson HD, et al. Micronutrient concentrations in the HIV wasting syndrome. AIDS 1993; 7: 15951600 .

31. Kupka R, Msamanga GI, Donna S, et al. Selenium status is associated with accelerated HIV disease progression among HIV-1-infected pregnant women in Tanzania. J Nutr 2004; 134: 2556-2560.

32. Graham NM, Sorensen D, Odaka N, et al. Relationship of serum copper and zinc levels to HIV-1 seropostivity and progression to AIDS. J Acquir Immuno Defic Syndr 1991; 4: 976-980.

33. Khalili A, Soudbakhsh A, Hajiabdolbaghi M, et al. Nutritional status and serum zinc and selenium levels in Iranian HIV infected individuals. BMC Infect Dis 2008; 8: 165.

34. Moreno T, Artacho R, Navarro M, et al. Serum copper concentration in HIV-infection patients and relationships with other biochemical indices. Sci Total Environ 1998; 217: 21-26.

35. Ucar SK, Coker M, Sözmen E, et al. An association among iron, copper, zinc, and selenium, and antioxidative status in dyslipidemic pediatric patients with glycogen storage disease types IA and III. J Trace Elem Med Biol 2010; 24: 42-45.

36. Ferns GA, Lamb DJ, Taylor A. The possible role of copper ions in atherogenesis: the Blue Janus. Atherosclerosis 1997; 133: 139-152.

37. Mazur A, Gueux E, Bureau I, et al. Copper deficiency and lipoprotein oxidation. Atherosclerosis 1998; 137: 443-445.

38. Ferencík M, Ebringer L. Modulatory effects of selenium and zinc on the immune system. Folia Microbiol (Praha) 2003; 48: 417-426.

39. Fraker PJ, King LE, Laakko T, et al. The dynamic link between the integrity of the immune system and zinc status. J Nutr 2000; 130: 1399S-1406S.

40. Percival SS. Copper and immunity. Am J Clin Nutr 1998; 67: 1064S1068S.

41. Fawzi W. Micronutrients and human immunodeficiency virus type 1 disease progression among adults and children. Clin Infect Dis 2003; 37: S112-S116.

42. Abdulla M. Trace elements and free radicals in health and disease: Essential and Toxic Trace Elements in Human Health and Disease. Alan R. Liss, New York 1998; p. 277-292.

43. Chandra RK. Effect of vitamin and trace-element supplementation on immune responses and infection in elderly subjects. Lancet 1992; 340: 1124-1127.

44. Beisel WR. Metabolic responses of the host to infections: Textbook of pediatric infectious diseases. WB Saunders Co, Philadelphia 1998; p. 34-40.

45. Olivares M, Uauy R. Copper as an essential nutrient. Am J Clin Nutr 1996; 63: 791S-96S.

46. Bogden JD, Kemp FW, Han S, et al. Status of selected nutrients and progression of human immunodeficiency virus type 1 infection. Am J Clin Nutr 2000; 72: 809-815. 
47. Bogden JD, Baker H, Frank O, et al. Micronutrient status and immunodeficiency virus (HIV) infection, micronutrients and immune function: cytokines and metabolism. Ann NY Acad Sci 1990; 58 : 189-195.

48. Lai H, Lai S, Shor-Posner G, et al. Plasma zinc, copper, and mortality in HIV-1 infected homosexual men. Int Conf AIDS 1998; 12 34-35.

49. Quiros-Rolden E, Raffetti E, Donato F, et al. Neutrophil to lymphocyte ratio and cardiovascular disease incidence in $\mathrm{HIV}$-infected patients: a population-based cohort study. PLos One 2016; 11: 1-11.

50. Raffetti E, Donato F, Pezzoli C, et al. Systemic Inflammation-Based Biomarkers and Survival in HIV-Positive Subjects With Solid Cancer in an Italian Multicener Study. J Acquir Immune Defic Syndr 2015; 69: 585-592.

51. Raffetti E, Donato F, Castelnuovo F, et al. The prognostic role of systemic inflammatory markers on HIV-infected patients with non-Hodgkin lymphoma, a multicenter cohort study. J Transl Med 2015; $13: 89$.

52. Tenorio AR, Zheng Y, Bosch RJ, et al. Soluble markers of inflammation and coagulation but not T-cell activation predict nonAIDS-defining morbid events during suppressive antiretroviral treatment. J Infect Dis 2014; 210: 1248-1259.

53. Ross AC, Rizk N, O'Riordan MA, et al. Relationship between in flammatory markers, endothelial activation markers, and carotid intima-media thickness in $\mathrm{HIV}$-infected patients receiving antiretroviral therapy. Clin Infect Dis 2009; 49: 1119-1127.

54. Benites-Zapata VA, Hernandez AV, Nagarajan V, et al. Usefulness of neutrophil-to-lymphocyte ratio in risk stratification of patients with advanced heart failure. Am J Cardiol 2015; 115: 57-61.

55. Park JJ, Jang HJ, Oh IY, et al. Prognostic value of neutrophil to lymphocyte ratio in patients presenting with ST-elevation myocardia infarction undergoing primary percutaneous coronary intervention. Am J Cardiol 2013; 111: 636-642.

56. Pugliese C, Patin RV, Palchetti CZ, et al. Assessment of antioxidants status and superoxide dismutase activity in HIV-infected children. Braz J Infect Dis 2014; 18: 481-486.

57. Dworkin BM. Selenium deficiency in HIV infection and the acquired immunodeficiency syndrome (AIDS). Chem Biol Interact 1994; 91 181-186.

58. Seifried HE, Anderson DE, Sorkin BC, et al. Free radicals: the pros and cons of antioxidants. American Society for Nutritional Sciences. J Nutr 2004; 134: 3143-3163. 